\title{
Financial Inclusion as an Effective Policy Tool of Poverty Alleviation: A Case of Ekiti State
}

\author{
*Ogunsakin, Sanya (Ph.D) ${ }^{1}$, Fawehinmi Festus Olumide \\ ${ }^{I}$ Department of Economics, Faculty of the Social Sciences, Ekiti State University, Ado-Ekiti, P.M.B. 5363, Ekiti \\ State, Nigeria. \\ *Corresponding Author: Ogunsakin, Sanya (Ph.D)
}

\begin{abstract}
This study examined the financial inclusion as an effective policy tool of poverty alleviation in Ekiti state from 1980 and 2015. Random sampling technique was employed to sample 180 adult households across the three senatorial districts of the state. The data used for the study were obtained with the use of well structured questionnaires. Descriptive statistics and multinomial logit were used to empirically analyze the results. Findings from the study revealed that -poverty rate was higher among women. Women accounted for about 58\% of the poor while men accounted for $42 \%$. The study discovered that the numbers of commercial banks across the three senatorial districts of the state were extremely low. The available ones were only concentrated in state Headquarters, (Ado-Ekiti). The study equally found that the size of financially excluded population Ekiti state was high (45\%). That shows that financially included population in Ekiti state was basically among civil servants and few business men during the study period. The study found that the following factors were major determinants of poverty and financial inclusion in Ekiti State during the study period. The factors are; employment, marital status, educational level, religion, financial discipline, use of banks products and services, distance, household size, access to political contract, gender, income level and age. Based on these findings, it is recommended that more commercial bank branches and cash centres should be opened across the three senatorial districts of the state. More bank products and services should be introduced such as grants, overdraft and special funds that can easily be accessible by customers.
\end{abstract}

Keywords: Financial Inclusion, Poverty, Multinomial Logit and Ekiti state.

\section{Introduction}

The issue of poverty has become an indelible problem across nations because no nation either developed or developing can be adduced to be devoid of the world poverty. This is because poverty is a unique and complex phenomenon. The features of this uniqueness are particularly prominent in the third World countries (African countries inclusive)

In Africa, particularly in Nigeria, several attempts and approaches had been adopted by various governments to reduce or alleviate this problem (poverty). Some of these approaches are; Green Revolution by Shagari Administration in 1980's, operation feed the nation by Obasanjo Administration in 1978, Better life by Babangida, 1986 and several other poverty alleviation strategies. However, despite these various poverty alleviation strategies, Nigeria is yet to transform these with her resources both human and material into reasonable and significant welfare improvement for the majority of its population and to relative reduce the growth rate of poverty.

Moreover, in an attempt by Government and Non Governmental Organizations to review these earlier strategies, the issue of Financial Inclusion that has been employed especially in developed economies as one of the effective poverty alleviation strategies was introduced. Financial inclusion has been identified as one of the effective policy tools used by government developed countries in fighting and reducing poverty level given its ability to facilitate efficient allocation of productive resources, that reducing the cost of capital. Maitinez, (2011): This process is otherwise referred to as an inclusive financing system which can significantly improve the day to day management of finances, as well as reduce the growth of informal sources of credit (such as money lenders) Onaolapo, (2015). Also, various government in Nigeria past and present have adopted several Financial sector reforms to achieve efficient allocation of resources in order to enhance the performance of Financial sector, Macro-economic performance and to better the living standard of Nigerians. Some of these reforms were aimed to harmonize Nigerians who had been vehemently isolated from former Financial sector. The size of the financially excluded population in the world is enormous according to the United Nations, approximately three billion people around the globe lack access to formal financial services - such as bank account, credit, insurance, a safe place to keep savings and a secure and efficient means to receive social benefit 
payments through a registered financial institution (Umoh, 2007), and (Chibba, 2008) as cited by (Micheal, 2009). Although the problem is global but more preannounced in developing nations. Financial inclusion, within the broader context of inclusive development, is viewed as an important means to tackle poverty and to some extent to reducing the gap between the rich and the poor.

In the last decade, Nigeria has a recorded a significant and consistent improvement in the economic growth, macroeconomic performance, Economic stability democracy and reform as noted by (World Bank, 2013) except the recent recession which started in the late 2014 as a result of sudden reduction in crude oil price at international oil market. Also, reports from Nigeria Bureau of statistics (2014) indicates that Nigerian economic showed very strong growth rate of GDP over the last decades, an average of $8 \%$.The reports further showed that Nigerian Economy is $17 \%$ time larger today than at the beginning of the decade and growth in the non-oil economy has been higher, almost $240 \%$ times higher than decade ago.

It is hard to note that despite these recorded improvements in the growth rate of output in official statistics, Nigeria is yet to use the proceed from this to better the lives of her citizenry. The poverty situation in Nigeria is considered paradoxical. This is because, Poverty in the means of plenty.

Although, financial inclusion has become topical on the global policy agenda for sustainable development, economic literature on financial inclusion is still in its infancy. Most studies have looked into the appropriate measures of financial inclusion both at household and country levels, while some studies concentrated on the role of financial access in lowing poverty and income inequality. However, these studies have provided foundations in this field and give key policy insights on the importance of financial inclusion on sustainable development (Cyn-young, 2015). As majority of these studies provide valuable information on the effectiveness of financial inclusion as one of the effective policy tools to reduce poverty but relied on secondary data. As good as secondary data are, cannot accurate capture the extent of financial inclusion at individual level, apart from this, the individual poverty level, can only be accurately captured with interacting with such individual by directing questions concerning to their level of satisfaction, happiness and extent of deprivation on basic necessities of living.

In Ekiti State, studies on financial inclusion and poverty remain scarcity Adamolekun, (2008) in his study reveals that relationship between microfinance and poverty was proportional. That is, the higher the level of microfinance likeLapoo and seap, the higher the level of poverty. Also, Fagbuaro, (2014) found positive relationship between microfinance and poverty in some selected local governments in Ekiti State.

Based on the issued raised in the last two paragraphs of this introductory section, this paper is out to contribute to this contending issue. The reminder of the paper is structured as follows, this introductory section is followed by section two that discusses some related concepts, and empirical literature. Section three concerns with theoretical underpinning, method and materials while section four presents and analyses of the results. Section five concludes the paper.

\section{Literature Review}

In this section, some concepts are being clarified, theories and empirical literature on financial inclusion and poverty are presented.

\section{Concept of Financial Inclusion}

Financial exclusion serves to prevent certain social groups and individuals from gaining access to the formal financial system (Leyshon and Thrift, 1995), (Caro, 2005) (Mohan, 2006) see financial inclusion as lack of access by certain segment of the population to appropriate, low - cost, fair and safe financial products and services from mainstream providers are measures of financial inclusion. Financial inclusion is a broad concept, defines by (Sarma 2008), is the process that ensures the ease of access, availability and usage of formal financial system. It is essential to differentiate between voluntary versus involuntary exclusion. The (World Bank, 2004) defines voluntary exclusion as a condition where the segment of the population or firms choose not to use financial services either because they have no need for them or due to cultural or religions reasons. In contract, involuntary exclusion arises from insufficient income and high risk profile or due to discrimination, market failures and imperfection (Cyn -Young \&Rogalio 2015) It should be noted that the world financial inclusion was derived from British lexicon as they discovered that almost 7.5 million population did not have formal bank Account (Raju, 2006). The term financial inclusion came into existence in Nigeria after structural adjustment programme (SAP). Moreover, there are two notable dimensions of financial inclusion. These are the focus dimension and the degree dimension. The focus dimension links the other dimensions of exclusion. This dimension, considers the potential challenges encounter by some segments of the population, viz individual, household, or communities in accessing mainstream financial services. However, the degree dimension is the narrowest of all and defines financial exclusion as the prevention from the usage of particular sources of credit and other financial services including insurance, bill payment services and accessible and appropriate deposits account. 


\section{Concept of Poverty}

The word poverty derived from Latin word known as pauper meaning poor World Bank, (1997) defines poverty as hunger, lack of shelter, sickness and inability to attend school, inability to read and write, joblessness, fear for the future, highly infant and child mortality.

(Aku, Ibrahim \&Bulus, 1997), define poverty from five perspectives as personal and physical deprivation experienced as a result of health, nutrition, literacy and educational disability and lack of self confidence, Economic deprivation due to lack of access to property, income assets, factors of production and finance, social deprivation brought about as a result of denial from full participation in social, political and economic activities, cultural deprivation in terms of lack of access to values, beliefs, knowledge, information and attitudes which deprived the people of the ability to control their personal destinies and political deprivation emanating from lack of political voice to participate in decision making that affect their lives.

In addition to the above definitions, poverty can be grouped into four. Namely, Absolute, which is otherwise, be known as object or chronic, relative, disguise and poverty of mind. The term absolute poverty is a generalized terms that peculiar to developing nations. That is inability to provide the basic necessity of life. Cloth, feeding and shelter. Relative poverty on her own relates the standard of living of the poor to the standards that holds elsewhere in the society in which they live. Therefore, relative poverty is saying a state of comfort may be a state of discomfort for another. Disguise poverty centers on some individuals using the porous in the system to make a living which cannot be a continuous exercise. A good examples of these are the case of some politicians prostitutes, free fraud syndrome known as 419, internet fraud popularly known as yahoo or plus. Poverty of mind: This is inability to be self contented, that is, to be pleased with what an individuals have in hand.

\section{Linkages between Financial Inclusion And Poverty}

An effective financial inclusion policies impact economies as it contributes to the reduction of poverty, pro-poor growth and accelerated economic growth. (Onaolupo, 2015), in a related studies. Levine, (2005) summits that institutional infrastructure of the financial system contributes to reducing financial information asymmetry, contraction in transaction, costs, which in turn reduce poverty and increase the level of economic growth. (Collins, 2009) as cited by (Onaolupo, 2015) found causality between access to a range of appropriate and affordable financial services and improvement in poor people's welfare and income. To support the previous view on this issue, (Demirque-kunt, 2008) says that inclusive access to finance is not only pro-growth but also pro-poor as well as reducing income inequality and poverty. Financial inclusion is essential to put in place inclusive growth and it is a condition for sustainable economic growth and development. Harnessing the power of technology is one of the most effective ways of integrating the unbanked population into the financial mainstream. Technology enables the provision of a host of services from depositing money into various government schemes to micro loans and micro insurance.

\section{Financial Inclusion in Nigeria}

Several financial sector reforms had taken place in Nigeria not only to reduce bank desress but also to promote the ability of banks to grant soft loan to entrepreneur to increase their level of productivity in order to reduce the poverty rate: Despite these positive strife by government, Nigerian bank are yet to include the vast segment of the population. The Nigerian banking industry has not less than 5,997 bank branch 18,958 ATMs and 11,223 POS terminals (CBN, 2014). It is on record that Nigerian's bank population has grown tremendously, but the expected infrastructural base is operating below its potential and has the capacity to serve more customers. The average number of clients per branch was 3,882, compared to 3,722 in Kenya and 8,595 in Tanzania (C. B. N, 2012) to reach best class levels, the average branch should serve more than double the number of clients it serves today. Hence, Nigeria lags behind some its peer African countries with regards to the provision of financial services (Solomon Olajide, 2014). A survey by EFIA (2010) showed that about $36 \%$ (31 million) adults out of adult population (18 years above) of 84.7 billion were served by formal financial services while $46.3 \%$ (39.2) and $17.4 \%$ (14.7 million) were formally served and financing excluded respectively. Out of adults who were formally served only $30 \%$ (25.4 million) used money deposit bank (mostly commercial banks) while 6.3\% (5.3 million) used other formal institutions and financial products not supplied by deposits money banks. The financial access by gender show the $62.6 \%$ adult males and $72.8 \%$ adults females are unbanked. Only $37.4 \%$ male and $27.2 \%$ female have access to financial services. $76.8 \%$ adults who are banked mostly use it for salaries and wages while $15.7 \%$ adults who are banked are traders who use it for business transactions. Only $14.9 \%$ farmers are financially included while $74.9 \%$ are financially excluded (Fodun, 2014). 
Financial Inclusion as an Effective Policy Tool of Poverty Alleviation: A Case of Ekiti State

Table 1: current state of financial inclusion in Nigeria

\begin{tabular}{|l|l|l|l|l|l|l|l|}
\hline & 2012 & $\%$ & Total No (M) & $\%$ & Total No & $\%$ & Total No (m) \\
\hline & 76.8 & 100 & 84.7 & 100 & 87.9 & 100 & 93.9 \\
\hline Adult population & 21.1 & 30.0 & 25.4 & 32.5 & 28.6 & 36.6 & 33.9 \\
\hline Financially served & 2.5 & 16.3 & 30.7 & 10.5 & 9.2 & 12.3 & 11.5 \\
\hline Financially excluded & 23.9 & 17.4 & 14.7 & 17.3 & 15.2 & 11.9 & 11.2 \\
\hline Formally served (included) & 52.5 & 46.3 & 39.2 & 39.7 & 34.9 & 39.5 & 36.9 \\
\hline Informally served (included) & 47.5 & 53.7 & 70.8 & 60.3 & 53.0 & 60.5 & 56.6 \\
\hline Banked & 23.6 & 36.3 & 56.1 & 4.30 & 37.8 & 48.6 & 45.4 \\
\hline
\end{tabular}

Source: EFInA Access to financial services in Nigeria, 2014 survey.

From the above table 1, a survey by EFInA that took place between July to September 2014 showed that out of Nigerian adult population estimated to be 87.9 million across all the thirty six states of the federation showed that only $43 \%$ representing 37.8 million adults had access to financial services. Only $32.5 \%$ representing 28.6 million adults had access to deposit money bank other adult who had access and used other formal financial products did not supply by deposit money bank including insurance, pension-scheme. Those adult that did not have access to bank account and other financial services and product such as Awiko cooperative societies, Esusu and Ajo were 17.3\% representing (15.2 million). Therefore, 39.7\% representing 34.9 million were financially excluded.

Table 2: Characteristics of Financial Inclusion across Region in Nigeria

\begin{tabular}{|l|l|l|l|l|l|}
\hline Zone & $\begin{array}{l}\text { Formally Banked } \\
(\%)\end{array}$ & $\begin{array}{l}\text { Formally other } \\
\%\end{array}$ & $\begin{array}{l}\text { Informally served } \\
(\%)\end{array}$ & $\begin{array}{l}\text { Financing Excluded } \\
(\%)\end{array}$ & Total \\
\hline North West & 13 & 6 & 13 & 68 & 100 \\
\hline North Central Inc FCT & 27 & 6 & 23 & 44 & 100 \\
\hline South West Inc lags & 42 & 7 & 18 & 33 & 100 \\
\hline North East & 15 & 6 & 11 & 68 & 100 \\
\hline South East & 41 & 6 & 21 & 32 & 100 \\
\hline South South & 39 & 6 & 19 & 36 & 100 \\
\hline
\end{tabular}

Source: EFInA Access to financial services in Nigeria publications

The above table 2 shows geographical difference of financial inclusion in Nigeria. Information from the table reveals that financial inclusion is mostly popular in the urban area of Nigeria, especially in the southern parts of the country. Northern Nigeria is particularly at disadvantaged as high as $68 \%$ of adults both in the North East and north West zones are excluded from financial services as against 33\% and 32\% for South West and South East respectively. Rates of formal inclusion range from $49 \%$ in the South West Region to only $19 \%$ in the North West Region. Informally included are more in the North Central region, where $23 \%$ of the adults have access to only informal services. Furthermore, majority (80.4\%) of those who are fully excluded from formal and informal financial services live in rural areas, while the remaining 19.6\% live in urban areas (EFInA, 2010) (Solomon, 2014), Three potential explanations are possible firstly, the physical distance to bank branches in most areas is long and this poses high cost for accessing financial services. Secondly, the lower Economic activity in rural areas limits the profitability of financial institutions. Thirdly, a commonly low degree of education and financial literacy in rural areas decreased the probability for clients to make use of financial products and services (Solomon, 2014).

Financial inclusion initiative in Nigeria, several efforts have been made by the Central Bank of Nigeria and other stakeholders in the banking industry to reduce to number of financial excluded Nigerians. This is to be achieved by implementation of NFIS. The essence of INFIS is to reduce the number of Nigerians that are excluded from financial services from $46.3 \%$ to $20 \%$ by 2020 and increase the number of Nigerians that are included in the formal sector from $33 \%$ to $70 \%$ by the year 2020 C.B.N, (2012). The stakeholders in enhancing the nations financial inclusion, are banks, other financial institutions, insurance, regulators, technology/telecommunications firms, public institutions and development partners/experts, (CBN, 2012) meanwhile, (EFInA2010) survey identified five major constrains to financial inclusion in Nigeria, low and irregular income, physical access, financial literacy, affordability and eligibility. Out of these, three key barrias are accessibility, eligibility and financial literacy. Financial literacy awareness and understanding of financial terms differ according to complexity of the product and product features, as well as commonality of product use within population. (Solomon, 2015). There are five major sources of financial information in Nigeria. Family and friends, someone trusted in the community, religious lenders, bank employer, work colleagues, electronic and print media by relevant stakeholders EFInA, (2010) as cited by (Solomon, 2015). 


\section{Empirical Literature}

Some studies have been conducted on the relationship between financial inclusion and macroeconomic variables especially in developed nations, but very scanty studies have been carried-out in developing countries especially Nigeria. Some of these studies are presented. (Dunn \& Arbuckle, 2001) study the impact of micro credit on the Bibanco clients in paru. The study employs cross sectional data taken in two parts one in 1997 and another one in 1999. Results from the study shows significant positive impact of microfinance on clients in term of income and employment generation. In a related study(Chibba, 2015), examines the impact of financial inclusion on poverty reduction, income distribution and achievement of millennium Development Goal in emerging economies. The study makes use of descriptive analysis as estimation technique. Findings from the study reveal five key pillars that are prerequisite to financial inclusion, the financial exclusion poverty are private sector development, financial literacy, microfinance and public sector support.

To support the view of the previous authors on financial inclusion, (Cyn-young \&Royelio, 2015) investigate the impact of financial inclusion on poverty and income inequality in developing Asian countries. The study makes use of both descriptive and inferential techniques. However, the two research questions were raised and tested. The first points to the factors that influence the level of financial access, where the second points to impact of financial accessibility on poverty reduction and redistribution in developing Asian countries. Findings from the empirical results show that certain factors greatly influence impact of financial inclusion on both poverty and income inequality during the study period. The factors are per capital income, rate of land and demographic structure. The results from this study is compatible with the findings from (Honohan, 2008) who construct a financial inclusive index for one hundred and sixty nations employing data both from household survey and the publications of various financial institutions. Ordinary least square (OLS) is employs as estimation technique. Finding from the study reveals that accessibility to financial inclusion significantly redistributes income and reduces poverty during the study period. In consonance with the above studies from some developing nations. (Onaolapo, 2015) studies the effects of financial inclusion on the growth of Nigerian economy between 1982 and 2012. The study employs Ordinary Least Square as estimation technique. Findings from the study show that inclusive Bank financial activities greatly influenced poverty reduction but marginally determined national Economic Growth and financial intermediation through enhanced Bank Branch Networks, Loan to Rural Areas, and Loan to Small scale Enterprise. Given what 50\% relatedness between variables on either sides of the equations. To support the view of financial inclusion as an effective tool of poverty reduction and income redistribution in Nigeria, (Solomon, 2014) studies financial inclusion, tool for poverty, alleviation and income redistribution in developing countries: Evidences from Nigeria. The study makes use of descriptive analysis as estimation technique. Findings from the study show that financial inclusion constitutes important tool for alleviating poverty and redistributing income in developing countries particularly in Nigeria. Also to strengthen the above studies in Nigeria (Taiwo \& Ismail, 2013) examine the relationship between sustainable financial services and poverty reduction in Nigeria between 1965 and 2010. Co-integration and Error Correction is used as estimation technique. Findings from the study show that accessibility to financial services reduces poverty during the study period. Summarily, from above few studies, majority of the studies were carried out in developed nations. The few studies that were done in Nigeria were so generalized. That is, based on entire Nigeria and relied majorly on secondary data. In Ekiti State, one can only mention one or two studies which are only on microfinance not entire financial inclusion. Therefore, in this paper, primary data is employed and all the three senatorial districts in Ekiti State are considered. In this section, the theoretical underpinning for the study, research design population sample, sampling techniques, research instruments, model specification, procedures for data collection and methods of data analysis are presented.

\section{Theoretical Underpinning}

The theoretical framework for this study is from the cumulative and cyclical interdependencies theory. The theorysees individuals and their communities caught in an unbroken spiral of opportunities and problems. The theory believes that when problem dominates, they close other opportunities and create a cumulative set of problems which may likely render any effective response or intervention useless or impossible. The theory further stipulates that individual situations and community resources are mutually dependent in the sense that a weak economy creates individuals who lack resources to fully participate in the economy. This situation therefore makes economic survival difficult for the commodity because the community will only be able to raise small amount from taxation.

\section{Research Design \\ The Research Design}

The study employs cross sectional survey research design which involves seeking response from households chosen from the population. The study sample from which inferences about population can be drawn is required because of the challenges of studying the entire population. Survey research is preferred for the 
evaluation and assessment of specific characteristics of large sample of people. From the data collected through the questionnaire administered, the design allows for a more inference about the factors underlying the whole population survey research would also make for easy analysis of the household level of financial inclusiveness.

\section{Population}

The aim of this paper is to examine the impact of financial inclusion on poverty alleviation in Ekiti State. Therefore, all the adults Household in the sixteen Local Government areas of Ekiti State are considered. The state is located in the South Western part of Nigeria and falls on Longitude $4^{\circ} 45^{1}$ and $5^{\circ} 45^{1}$ East of the green wish meridian and latitudes $7^{\circ} 15^{1}$ North of the equator. It has a total of sixteen Local Government areas, with an estimated population of 2,384212 population census (2006). The state is caved out of her sister state, Ondo state in October 1996 by then Head of State, Late General Sanni Abacha.

\section{Sample and Sampling Techniques}

The sample for this study consists 180 adults household that are selected from all sixteen Local Government areas of the Ekiti State used multistage sampling technique. The first stage is the selection of two Local Government Areas randomly from each of the three senatorial districts, giving a total of six Local Government Areas in all. The second stage is the selection of one rural area and one urban area from each of the six Local Government Areas. The last stage is the random selection of fifteen adults from each of the selected rural and urban areas a total of 180 respondents. Some questionnaire are wrongly filled and not counted, therefore only 162 adults households are used for the analysis.

\section{Research Instrument}

Data were collected for analysis through the use of questionnaire. The question centered on financial inclusion as an effective policy tool for poverty alleviation in Ekiti state. It was a self constructed questionnaire in which variables selected were from a thorough review of related literature consulted during the study. The instrument was made up of two sections.

Section A: This section collects necessary information on bio-data of the respondents such as age, sex, marital status and level of education.

Section B: This section collected necessary information of family/household characteristics, such as level of income, usage of account, employment status household size, Distance, religion, mental status etc.

\section{Validity of the Instrument}

To ensure the validity of the instrument, the face and the content validity were ascertained by the researcher. In term of face validity, the researcher ensured the physical appearance of the test items, the layout of the test items, the arrangement of items types of lettering used etc. In term of content validity of the instrument, some experienced researchers in this field were consulted for guide on the items on the instrument. Based on their inputs and suggestions, amendment were made and the instrument was restructured to meet content validity.

\section{Reliability of the Instrument}

After the instrument had been validated, retest method was used for reliability of the instrument. Two towns were selected to experiment. The two towns are Otun in Moba Local Government and Ilawe-Ekiti in Ekiti South West. Results are presented and discussed in this section. Because of space constraint only the characteristics of individual respondent across the three senatorial district and the impact of financial inclusion as an effective policy tool for poverty alleviation being our target variables are presented.

\subsection{Characteristics of individual Respondent across the three senatorial district in Ekiti State.}

The information from survey study on individual across the three senatorial districts is provided in the table 4.1 in the appendix. The respondents are divided into poor and non-poor based on the extent of deprivation of basic requirements of life. However, this division into poor and non-poor is made possible through a set of questionnaires administered to respondents that captured the extent of life deprivation, life happiness, life satisfaction and enjoyment.

From the results obtained from randomly selected two Local Government areas in each of three senatorial district of Ekiti State, the number of poor is higher than the number of non-poor. That is, the number of poor 95 against 67 non poor. To establish if the mean values of individual variables between poor and nonpoor are statistically significant, $\mathrm{t}$ - test is employed and to establish the relationship between the discrete variables and poverty level, the popular chi-square is used. As regards the gender, female accounts for higher number of poor with almost fifty eight percent (58\%) against their male counterpart that accounts for forty two percent $(42 \%)$, it is established that there is a positive correlation between the likelihood to be poor and non- 
poor and gender $\left(x^{2}=31.46\right)$. this determines to so extent the level of poverty. The age of the respondent was divided into four categories that follows this pattern 18-30 years, 31-40, 41-60 and 61 years and above. Results show that poverty was prominent and high within the age bracket $31-40$ years and $41-60$ years with 33 percent and 32 percent respectively.

On the level of education, respondents with better qualifications were relatively excepted from poverty and poverty was so high among respondents that were less - educated. Respondents with B.Sc and H.N.D formed the highest of respondents that were relatively free from poverty. As regards the employment status, the civil servants among the respondents constitute the highest proportion of poverty free individuals with almost 53 percent of the entire sample. The unemployed, with 64.2 percent of the poor group only constitute 14 percent of poverty victim.

The demographic classification of respondents shows that divorced widow, widower, and single constitute the higher percentage of poverty victim (65 percent). However, married constitute the lowest proportion of poverty victims (35) percent. Results on 4.3 further show that the categorization of respondents into income group and their respective distribution based on poverty. Respondents with higher income, that is with income of N40,000 to N80,000 constitute the lowest proportion of poverty. While those respondents with income below N18,000 per month constitute the highest poverty victim. The Chi-square shows a negative relationship between income and poverty. That is, the lower the income, the higher the poverty level and verse versa. Coming down to the size of the household, the results on the table show positive relationship between the size of the household and poverty level. That is, the higher the size of the family or household, the higher the level of poverty.

The results further show that respondents with formal banks account and that, equally manage the account are living above poverty. Also, respondent with no official account or who have accounts that are dormant constitute the higher proportion of poverty victims. Also from the table, the respondents who were financially disciplined or prudent account for amount 82 percent of those respondents who are living above poverty.

\subsection{Determinants of financial inclusion}

Table 4.4 in the appendix shows the result of multinomial logit analysis from the results, household, size shows a positive and significant relationship with poverty. This shows that the number of people in the family greatly determines the level of poverty. That is the higher the number of household, the higher the poverty level. These sets of family will be living from hand to mouth. This result is compatible with Oluwasola and Alimi (2000) which says a large family often borrow to meet up the financial obligations of their family. Also, the variable financial discipline shows a significant and negative relationship with poverty. This shows that an individual who is financial discipline is better off in terms of welfare than financially indiscipline individuals. This result is inline with the finding of (Efobi, 2014) that an individual who is financially discipline is economically prudent and always avoid wastage and engage in productive investment to improve welfare.

Employment level shows a significant and negative relationship with poverty at 5\% level. This shows that, the respondents who are gainfully employed are better off and escape poverty. The level of income, marital status, age have positive and significantly different from zero at conservative $1 \%$ level of significant. The individual with high income is better off in term of living condition than individual with low income. Individual who are gainfully employed that have not married have higher probability of being not be a victim of poverty. From the results, individuals who are far away from banking services and products, that is, who are living in rural area have low probability of not being poor. Age also shows a significant and positive relationship with not being poor at conservative $1 \%$ level of significant. Finally, the chi-square $x^{2}$ displays a strong and reliable relationship between indicators of financial inclusion and poverty in Ekiti state. The $\mathrm{R}^{2} 0.734$.the implication of this is that almost $73 \%$ variations in the dependent variables are being explained by the explanatory variables. This implies that the major determinants of poverty and financial inclusion in Ekiti state are those factors identified during the study period.

\section{Summary And Policy Recommendations}

This study examined the effects of financial inclusion on poverty reduction in Ekiti state. The target population for the study comprised all the adult households in Ekiti state, Nigeria. The sample for the study consists 168 household drawn from six Local Government Areas of the state using multi stage sampling technique. Two communities were drawn from each of the Local Government Area, making a total of 12 communities. Fifteen households are randomly sampled from each of the twelve communities. The instrument employed was questionnaire. The questionnaire was a self constructed questionnaire in which variable chosen were from a thorough review of related literature. The instrument was exposed to both face and content validity by the researcher. The instrument was administered on the respondents by the researcher and some filed assistant who were familiar with the sample areas. Descriptive statistics and multinomial logit were employed 
for the analysis. The descriptive analysis of the data showed that the number of commercial banks across the state was extremely low. The commercial banks were concentrated in the state Headquarters (Ado-Ekiti) during the study period. In fact, majority of the selected Local Government had less than three commercial banks. Based on this, bank services and bank product were low, such as ATM, money transfer, union bank transfer etc. the study discovered that informal financial sector such as 'Awiko' contributions, Ajo, Esusu etc. were dominated savings and procurement of loans. The study found that the procedures for opening new accounts were somehow difficult that discouraged most of the intending savers and new account openers. The study discovered that bank robbery and money snatching were so rampant especially in the studied rural areas. The study however, discovered that the rate of patronage of bank services and bank products was higher among men from the study, it was revealed that poverty rate was higher among women. This is because men were more gainfully employed than women. The study discovered that the following factors are major determinants of poverty and financial inclusion in Ekiti state. They are, education level, marital status, financial discipline, employment status, religion, access to political contract, location, gender, income, household size and age. Based on these findings, it is recommended that more commercial banks braches and cash centres should be opened across the three senatorial districts of the state. If this is done, more banks products and services should be strengthened. Such as grants, loan, overdraft and special funds that can easily be accessible by customers.

\section{References}

[1] Adalessosi, K. (2015). The level of the Financial Inclusion in the African Countries and in the World Group Regions. China Review.Vol 14 No $3129-142$

[2] Adedigba, P.I. and Folorunsho. A (2008).Commercial Banks and Financial Development in Ondo State. Issues and Challenges. Ibadan, Alafas Nig. Ltd.

[3] Olaoluwa A.K (2015); Effects of Financial Inclusion of the Economic Growth of Nigeria: International Journal of Business and Management Review. Vol 3, no 8, pp 11-28.

[4] Martinez M.V (2011); The Political Economy of Increased Financial Access. A Thesis Submitted in partial fulfillment of the requirement of the Degreee of Master of Public Policy to the faculty of the Graduate School of Arts and Social Sciences of Georgetown University.

[5] World Bank (2008); Finance for all: Policies and fit Falls in expanding Access 'Washington DC', The World Bank.

[6] Levine (2005); 'Finance and Growth: 'Theory and Evidence' in Aghion and Durlauf (ed), Handbook of Economic Growth. Edition 1 , volume 1, chapter 12

[7] Sarman and Paris (2011). Financial Inclusion and Development: A Cross Country Analysis. Paper presented at the conference on Equity, Inclusion and Human Development. September 10-13, 2008: Organized by HDCA and 1 HD, New Palhi, India.

[8] CBN (2000). The Changing Structure of the Nigeria Economy and Implication for Development Lagos: Realm Communication/Central Bank of Nigeria.

[9] CBN (2013).Central Bank of Nigeria Annual Report and Statement of Accounts (Various Issues).

[10] CBN (2014).Central Bank of Nigeria Annual Report and Statement of Accounts (Various Issues).

[11] Chee-Keong, C and Chan, S-G (2010). 'Financial Development and Economic Growth. A review'.A publication in the African Journal of Business Management. 04/2011;5:2017-2027.

[12] Chibba, M. (2015).Financial Inclusion Poverty Reduction and Millenium Development Goals.European Journal of Development Research, vol(12) pp 234-248.

[13] Cyn-Young, P. and Rogelio, V.M (2015): Financial Inclusion, poverty and Income Inequality in Developing Asia. ADB Economics Working Paper Series no 426.

[14] Demircuc-Kunt, A., and Klapper, L, (2012).Financial Inclusion in Africa. World Bank Policy Research Working Paper, WPS6088. Available at http://elibrary.

[15] Demirgue-Kunt, A and maksimovic, V. (1998).Law, Finance and Firm Growth.Journal of Finance 53:2017-2137.

[16] EFInA (2008).Access to Financial Services in Nigeria 2008 survey. Retrieved from http://www.dalberg.ng.org

[17] EFInA (2010).Access to Financial Services in Nigeria 2010 survey. Retrieved from http://www.dalberg.ng.org

[18] EFInA (2012).Access to Financial Services in Nigeria 2012 survey. Retrieved from http://www.dalberg.ng.org

[19] EFInA (2014).Access to Financial Services in Nigeria 2014 survey. Retrieved from http://www.dalberg.ng.org

[20] Efobi, U., Beecroft, I., and Osabuohien, E. (2014). Access to and use bank services in Nigria: Micro-econometric evidence. Review of Development Finance. Retrieved at http://www.elsevier.com/locate/rdf

[21] Fadun, S.O. (2014). Financial Inclusion, Tool for Poverty Alleviation and IncomeRedistribution in Developing Countries: Evidence from Nigeria. Academic Research International Vol. 5(3).

[22] Ho, G. (2004). Rural Credit Markets inVietman: Theory and Practice. Retrieved from http://aede.osu.edu/resources/docs/pdf

[23] Levine, P. (2005). Finance and Growth: Theory, Mechanisms and Evidence, in Aghion. Handbook of Economic Growth Elsevier.

[24] Nwanko, O. (2014). Sustainability of Financial Inclusion to rural dwellers in Nigeria: Problem and way forward. Research Journal of Finance and Accounting vol.(5) pp 80-87.

[25] Odhiambo, N.M. (2005). Financial Development and Economic Growth in Tanzania: A Dynamic Causality Test. African Finance Journal 7(10:1-17). 
Appendix1.

Table 4.3: Demographic Classification of Respondent (Poor and Non Poor) based on Indicators of Deprivation.

\begin{tabular}{|c|c|c|c|c|c|c|c|}
\hline \multirow{2}{*}{$\begin{array}{l}\text { Demographics } \\
\text { Gender }\end{array}$} & \multirow{2}{*}{$\begin{array}{l}\text { Poor } \\
\text { Count } \% \text { to } \mathrm{N}_{1} \\
\text { to } \mathrm{N}_{1} \\
\mathrm{n}_{1}\end{array}$} & \multicolumn{2}{|l|}{ Financial Excluded } & Non-poor & \multicolumn{2}{|c|}{ Correspondent 163} & \multirow[t]{2}{*}{ Statistical test } \\
\hline & & Yo to N1 & \multicolumn{2}{|c|}{$\begin{array}{l}\text { Count \% } \mathrm{N}_{2} \\
\mathrm{~N}_{2}\end{array}$} & $\begin{array}{l}\text { Sub-total } \\
\mathrm{N}_{3}\end{array}$ & $\begin{array}{l}\mathrm{N} 4=\mathrm{N}_{1}+ \\
\mathrm{N}_{2}\end{array}$ & \\
\hline \multicolumn{8}{|l|}{ Age } \\
\hline $18-30$ & 36 & 45 & 40 & 48 & 76 & 47 & \\
\hline $31-40$ & 19 & 24 & 16 & 19 & 35 & 21 & \\
\hline \multicolumn{8}{|l|}{ Employment } \\
\hline Self employment & 15 & 19 & 20 & 24 & 35 & 21 & \\
\hline Unemployed & 45 & 56 & 36 & 43 & 81 & 50 & \\
\hline Civil Servant & 20 & 25 & 27 & 33 & 47 & 29 & $\mathrm{X}^{2} 741.6$ \\
\hline \multicolumn{8}{|l|}{ Education } \\
\hline No formal education & 14 & 18 & 18 & 22 & 32 & 20 & \\
\hline \multicolumn{8}{|l|}{ Local Govt AA } \\
\hline Moba & 34 & 43 & 50 & 60 & 84 & 52 & \\
\hline Ilejemeje & 46 & 57 & 33 & 40 & 79 & 48 & $\mathrm{X}^{2} 11.61$ \\
\hline \multicolumn{8}{|l|}{ Marital Status } \\
\hline Married & 35 & 44 & 36 & 43 & 71 & 44 & \\
\hline Single & 14 & 18 & 20 & 24 & 34 & 21 & \\
\hline Divorced & 18 & 22 & 18 & 22 & 36 & 22 & $81-61$ \\
\hline Widowed & 13 & 16 & 9 & 11 & 22 & 13 & \\
\hline \multicolumn{8}{|l|}{ Marital Status } \\
\hline Married & 14 & 17.5 & 23 & 27.7 & 37 & 22.7 & \\
\hline Single & 20 & 25 & 30 & 37.1 & 50 & 30.7 & \\
\hline Divorced & 30 & 37.5 & 20 & 25.6 & 50 & 30.7 & \\
\hline Widowed & 16 & 20 & 10 & 2 & 26 & 16 & $\mathrm{X}^{2} 95.22$ \\
\hline
\end{tabular}

Account Ownership

\begin{tabular}{|c|c|c|c|c|c|c|c|}
\hline Yes & 32 & 40 & 55 & 66.3 & 87 & 53.4 & \\
\hline No & 48 & 60 & 28 & 33.7 & 76 & 46.6 & $\mathrm{X}^{2} 116.21$ \\
\hline \multicolumn{8}{|c|}{ Household size } \\
\hline $9-2$ & 15 & 18.8 & 20 & 24.1 & 35 & 21.5 & \\
\hline $7-10$ & 30 & 37.5 & 18 & 21.9 & 48 & 29.4 & \\
\hline $11-15$ & 15 & 18.8 & 4 & 4.8 & 19 & 11,7 & $\mathrm{X}^{2} 120.22$ \\
\hline
\end{tabular}

Income

\begin{tabular}{|l|l|l|l|l|l|l|l|}
\hline $5000-7,500$ & 13 & 16.3 & 5 & 67.2 & 18 & 11 & \\
\hline $8000-14,000$ & 32 & 40 & 11 & 13.3 & 43 & 26.4 & \\
\hline $15-25,000$ & 20 & 25 & 21 & 25.3 & 41 & 25 & \\
\hline $18,000-45,000$ & 15 & 18.7 & 30 & 36.1 & 45 & 27.6 & \\
\hline $50,000-85,000$ & & & 10 & 12 & 10 & 6.1 & \\
\hline $90,000-120,000$ & & & 4 & 4.8 & 4 & 2.5 & 66.31 \\
\hline
\end{tabular}

Households in the urban area and $63.7 \%$ in the rural area use firewood as cooking fuel.

Appendix 2.

Table 4.4: Multinomial Logit Analysis for Financial Inclusion and Poverty.

\begin{tabular}{|c|c|c|c|c|c|c|}
\hline Variable name & $\begin{array}{l}\text { Estimated } \\
\text { Coefficient }\end{array}$ & P-Value & Odds Ratio & $\begin{array}{l}\text { Estimated Co- } \\
\text { Efficient }\end{array}$ & P-Value & Odds Ratio \\
\hline Constant & $\begin{array}{l}-0.410 \\
(2.086)\end{array}$ & 0.002 & - & $\begin{array}{l}-5.878 \\
(1.916)\end{array}$ & 0.012 & - \\
\hline Age & $\begin{array}{l}-0.016 \\
(0.028)\end{array}$ & 0.570 & 0.984 & $\begin{array}{l}0.020 \\
(0.025)\end{array}$ & 0.425 & 1.020 \\
\hline Income & $\begin{array}{l}0.417 \\
(0.184) \\
\end{array}$ & 0.042 & 1.517 & $\begin{array}{l}0.506 \\
(0.205)\end{array}$ & 0.006 & 1.658 \\
\hline Gender & $\begin{array}{l}-0.336 \\
(0.114)\end{array}$ & 0.003 & 0.715 & $\begin{array}{l}-0.384 \\
(0.106)\end{array}$ & 0.000 & 0.681 \\
\hline Household size & $\begin{array}{l}0.540 \\
(0.204)\end{array}$ & 0.004 & 1.716 & 0.535 & 0.002 & 1.707 \\
\hline Education & $\begin{array}{l}0.800 \\
(0.246)\end{array}$ & 0.001 & 2.226 & $\begin{array}{l}0.425 \\
(0.196)\end{array}$ & 0.003 & 1.530 \\
\hline Marital status & $\begin{array}{l}-0.989 \\
(0.372)\end{array}$ & 0.021 & 0.372 & $\begin{array}{l}-1.991 \\
(0.580)\end{array}$ & 0.001 & 0.136 \\
\hline $\begin{array}{l}\text { Employment } \\
\text { level }\end{array}$ & $\begin{array}{l}-6.533 \\
(0.802)\end{array}$ & 0.000 & 1.455 & $\begin{array}{l}-3.298 \\
(0.657)\end{array}$ & 0.000 & 0.037 \\
\hline
\end{tabular}


Financial Inclusion as an Effective Policy Tool of Poverty Alleviation: A Case of Ekiti State

\begin{tabular}{|l|l|l|l|l|l|l|}
\hline Distance & $\begin{array}{l}0.443 \\
(0.207)\end{array}$ & 0.000 & 1.557 & $\begin{array}{l}-0.305 \\
(0.125)\end{array}$ & 0.513 & 0.737 \\
\hline Trust & 0.243 & & & 0.887 \\
& $(0.317)$ & 0.363 & 1.275 & $0.591)$ & & \\
\hline Alternative & -0.660 & 0.252 & 0.517 & $\begin{array}{l}0.318 \\
0.503\end{array}$ & 0.528 & 1.374 \\
\hline Religion & $0.577)$ & & & 0.078 \\
& $(3.178$ & 0.405 & 1.194 & 0.612 & 1.081 \\
\hline
\end{tabular}

cFaddem pseudo $-\mathrm{R} 2=0.370$

Mode! Fitting information (chi square) $=329,701$, with

$\mathrm{P}$-value $=0.00$

Source: Result from the multinomial logit regression.

Reference category is financial inclusion standard errors are in percentages

Ogunsakin. "Financial Inclusion as an Effective Policy Tool of Poverty Alleviation: A Case of Ekiti State." IOSR Journal of Economics and Finance (IOSR-JEF) 8.4 (2017): 01-10. 